Review

\title{
Understanding Lolium rigidum Seeds: The Key to Managing a Problem Weed?
}

\section{Danica E. Goggin ${ }^{1}$, Stephen B. Powles ${ }^{1}$ and Kathryn J. Steadman ${ }^{2, *}$}

1 Australian Herbicide Resistance Initiative, School of Plant Biology (M086), The University of Western Australia, 35 Stirling Highway, Crawley, WA 6009, Australia; E-Mails: danica.goggin@uwa.edu.au (D.E.G.); stephen.powles@uwa.edu.au (S.B.P.)

2 School of Pharmacy and Queensland Alliance for Agriculture and Food Innovation, The University of Queensland, Brisbane, Qld 4072, Australia

* Author to whom correspondence should be addressed; E-Mail: k.steadman@uq.edu.au; Tel.: +61-7-3346-1886; Fax: +61-7-3346-1999.

Received: 30 July 2012; in revised form: 31 August 2012 / Accepted: 14 September 2012 / Published: 24 September 2012

\begin{abstract}
The 40 million hectare southern Australian winter cropping region suffers from widespread infestation by Lolium rigidum (commonly known as annual or rigid ryegrass), a Mediterranean species initially introduced as a pasture plant. Along with its high competitiveness within crops, rapid adaptability and widespread resistance to herbicides, the dormancy of its seeds means that L. rigidum is the primary weed in southern Australian agriculture. With the individuals within a $L$. rigidum population exhibiting varying levels of seed dormancy, germination can be staggered across the crop-growing season, making complete weed removal virtually impossible, and ensuring that the weed seed bank is constantly replenished. By understanding the processes involved in induction and release of dormancy in L. rigidum seeds, it may be possible to develop strategies to more effectively manage this pest without further stretching herbicide resources. This review examines L. rigidum seed dormancy and germination from a weed-management perspective and explains how the seed bank can be depleted by control strategies encompassing all stages in the lifecycle of a seed, from development to germination.
\end{abstract}

Keywords: after-ripening; dormancy; emergence; Lolium; longevity; no-till farming; persistence; ryegrass; seed; weed management 


\section{Introduction}

The Australian wool industry was the country's leading agricultural exporter in the mid- to late 19th century, had its last boom in 1950. Following this, wool prices dropped dramatically, and from the 1960s onwards some Australian farmers tended to concentrate on intensive cropping (primarily wheat) [1]. By the 1990s, continuous cropping was standard on many farms. An unforseen problem with this development is what was left behind when the sheep were removed from the land. Originally, sheep were fed on the native grass understorey of Eucalyptus woodland, but the extensive grazing led to dramatic changes in the native vegetation, and pasture grasses and legumes were introduced to improve the pasture. This was especially true in Western Australia, where the native plants were far less palatable than those in the east and so pastures became almost exclusively composed of Mediterranean annuals [1]. Once the land was dedicated to cropping instead of used for pasture, these species were transformed instantly from valuable sources of sheep nutrition to problematic weeds. First among these was Lolium rigidum.

\section{The Problem with Lolium rigidum}

As the genus Lolium was originally introduced into Australia from southern Europe and northern Africa as a pasture plant, the past 200 years have seen the repeated selection of highly productive strains adapted to local conditions [2]. The three outcrossing species of Lolium, L. rigidum Gaud. (annual or rigid ryegrass), L. perenne L. (perennial ryegrass) and L. multiflorum Lam. (Italian ryegrass), are capable of producing fertile hybrid offspring, resulting in an essentially continuous gradient of forms that can be difficult to classify into species [2]. Lolium rigidum is now a major weed of cropping systems worldwide, particularly in regions with a Mediterranean climate, and the cost of infestation in Australian agriculture is estimated to be hundreds of millions of dollars annually. The highly competitive nature of L. rigidum for the nutrients applied to crop fields leads to decreases in the number of fertile tillers and spikelets of the crop, resulting in significantly lower yields [3-5]. The success of $L$. rigidum as a weed is due to its high genetic variability, adaptability and fecundity, with reports of 45,000 seeds $\mathrm{m}^{-2}$ being produced in infested wheat fields [6]. Modern Australian cropping conditions are particularly suitable for $L$. rigidum infestation: the Mediterranean-type climate matches its region of origin, and fields are usually continuously cropped allowing the weed seed bank to accumulate rapidly [6]. Thus, the occurrence of L. rigidum is almost ubiquitous in southern Australian agricultural regions.

In 1968 , less than $20 \%$ of the area sown to cereals in southern Australia was treated with herbicides (predominantly 2,4-D) to control dicotyledonous weeds, and the idea that chemical control of weeds within cereal crops would ever become more than a supplement to cultivation was not seriously considered [7]. By 2010, the southern Australian grain belt had grown considerably in size (e.g., from 3.6 million to 14 million hectares in Western Australia alone) and the no-till cropping system, with its beneficial influence on soil erosion, water use efficiency and crop yields, predominated across the Australian dryland cropping region resulting in an almost exclusive reliance on herbicides to manage weeds [8]. Consequently, herbicide resistance in weeds has become one of the major challenges in modern Australian agriculture; in a survey of the Western Australian cropping region in 2003, over 
$60 \%$ of 441 tested L. rigidum populations were resistant to multiple herbicides [9]. Alternative strategies for weed removal are vital, and one approach with the potential to be very effective is to rid cropping fields of the weed seeds in the soil seedbank.

\section{Persistence and Dormancy of $L$. rigidum Seeds}

Although actively-growing and flowering plants are the visible manifestation of the weed problem, the hidden seed bank is equally, if not more, important in determining its severity. Depletion of the soil weed seed bank is therefore an excellent strategy to combat weeds, removing the infesting species before they can start to affect the young crop. However, seed dormancy and longevity add a degree of difficulty to this process. Many weed seeds, including those of L. rigidum, are dormant when shed. For example, the germination of freshly-collected seeds of L. rigidum populations collected from across the Western Australian grain belt ranged from 0\% to 70\%, depending upon location and year [10]. For the purposes of this review, viable seeds with germination $>80 \%$ will be referred to as "low-dormancy", and those with a germination $<20 \%$ will be considered as "high-dormancy". In Mediterranean-type climates, dormancy is a mechanism that prevents germination during sporadic, unpredictable summer rainfall events, when conditions are too dry and hot to permit successful seedling establishment. Thus, the viable seeds remain in the soil to germinate at a later date, i.e., after the crop has been seeded. A greater understanding of seed dormancy in L. rigidum, how it develops and evolves, and how it can be manipulated, could contribute greatly to weed removal within an integrated weed management programme.

\subsection{Persistence of L. rigidum Seeds in the Soil Seed Bank}

In general, the persistence of Lolium spp. seeds in the soil is short compared to many other invasive species [11], which is favourable from a weed management perspective as the viable seed bank can be depleted relatively rapidly and with less effort. Lolium rigidum seeds have been reported to persist in pots of soil for no longer than 16 to 18 months, regardless of burial depth $(5 \mathrm{~cm}$ or $10 \mathrm{~cm})$, soil type (clay or sandy loam) or rainfall pattern (summer or winter) [12], whilst approximately $1.5 \%$ of endogenous L. rigidum seeds in Western Australian no-till cropping fields (in which new seed set was prevented for the duration of the experiment) persisted for up to four years [13]. Lolium perenne appears to behave similarly to L. rigidum: when placed on the soil surface or buried at a depth of $2 \mathrm{~cm}$ or $5 \mathrm{~cm}$, only $1 \%$ of $L$. perenne seeds remained viable after one year under temperate climatic conditions [14]. Elsewhere, 4\% of L. multiflorum seeds buried in moist, well-drained soil at depths of $2-15 \mathrm{~cm}$ retained viability after three years, and $0.4 \%$ remained after seven years $[15,16]$ (see Figures 1-4 in [16] for curves showing the decline in seed viability in L. multiflorum and L. perenne seeds buried in both well- and poorly-drained soil). A period of survival in the soil even as short as 16 months is still sufficient for considerable release of dormancy over summer and autumn, and ensures that the seed bank will be replenished every growing season unless seed set is prevented in the new generation of plants. 


\subsection{Development of Dormancy in Maturing L. rigidum Seeds}

There is a strong interaction between genetics and environment in the determination of primary dormancy (e.g., [17]), and the genetic component is likely to be mediated by several different genes $[18,19]$. The environmental component can be mediated by temperature, moisture levels and abiotic stress. Under controlled conditions, L. rigidum mother plants or detached culms that experienced warm temperatures during seed development produced less-dormant seeds than those subjected to cool conditions [10,20]. Larger-scale analyses of the possible link between seed dormancy level and climate demonstrated that higher temperatures during seed set in spring (September) were correlated with lower initial dormancy and/or a faster rate of dormancy release via dry after-ripening (in which mature seeds gradually lose dormancy under warm, dry conditions) in L. rigidum populations collected from across the Western Australian wheat belt [10,21]. Lower rainfall during the growing season (May-October) also resulted in lower dormancy [10], but high rainfall at the start of summer (December) was correlated to a slower subsequent rate of dormancy loss via dry after-ripening [21]. Overall, however, it is likely that dormancy level is determined by local environmental conditions during seed development rather than by long-term climatic factors [21].

Shading of seeds by a plant canopy (thus enriching the proportion of green and far-red light and decreasing the photon flux density [22]) during their development could influence dormancy level if this process is dependent upon the quality and quantity of light reaching the young seed. Development and maturation of L. rigidum seeds under different light qualities had a relatively small effect on their dormancy level, but seeds produced under white or green light were more dormant than those under red or, particularly, blue light (Figure 1). Seed production under blue light was also much lower than under red or white light (data not shown), and these results reflect those of Ellery et al. [11], in which plants grown under shaded conditions produced smaller, less-dormant seeds. The fact that a very low proportion of the phytochrome pool would be in its active state under blue light [23] therefore suggests that phytochrome signalling may be involved in the development of dormancy as well as in mediating germination [24].

Different conditions within a single spike inflorescence may also affect the dormancy level of individual seeds. Seeds collected from the inflorescence base were more dormant than those from the middle of the inflorescence, and this was explained by the fact that during development seeds in different positions may experience differences in temperature and/or water content, as well as in resource partitioning, which could influence their dormancy status [25].

Hydration at cold temperatures commonly induces seeds of winter annuals to enter secondary dormancy [26], and this has been observed in L. multiflorum seeds buried for $60 \mathrm{~d}$ in moist soil (30\% moisture) experiencing temperatures around $0{ }^{\circ} \mathrm{C}$ [27]. However, induction of secondary dormancy in shallowly-buried L. rigidum seeds under Australian conditions is low and transient at best [28], as no evidence for dormancy induction has been observed during testing in our laboratory. 
Figure 1. Dormancy level of seeds matured under different light qualities. Flowering L. rigidum plants (50 plants per treatment) were enclosed in neutral, red, blue or green cellophane filters throughout seed development and maturation and received filtered sunlight at a fluence rate of $50 \mu \mathrm{mol} \mathrm{m} \mathrm{m}^{-2} \cdot \mathrm{s}^{-1}$. Seeds were harvested at maturity and germination (4 replicates of 50 seeds) was assessed $7 \mathrm{~d}$ after sowing seeds on $1 \%(\mathrm{w} / \mathrm{v})$ agar under conditions of $25 / 15{ }^{\circ} \mathrm{C}$ with a $12 \mathrm{~h}$ photoperiod. Different letters above columns indicate significant differences $(P<0.05)$ between means.

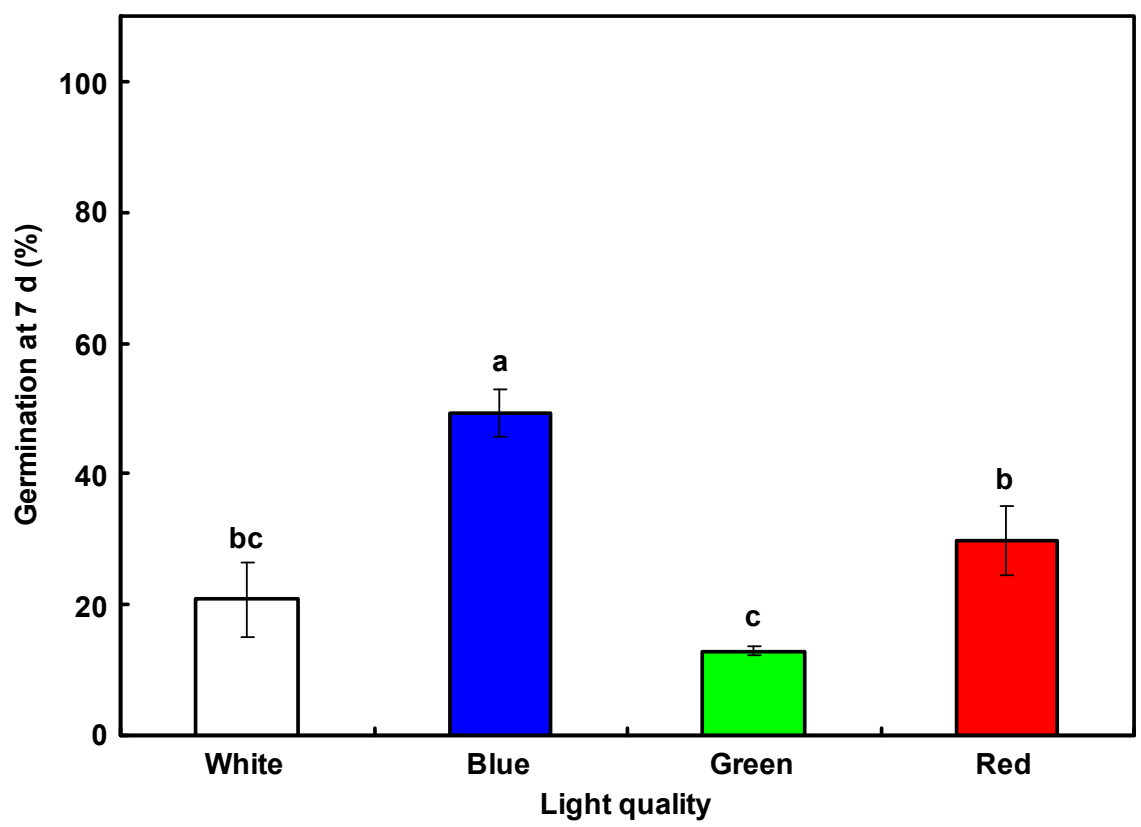

\subsection{Dormancy Release in Mature L. rigidum Seeds}

Freshly-harvested L. rigidum seeds, even if they exhibit only a low level of primary dormancy, have more stringent germination requirements than those that have lost dormancy via dry after-ripening. Populations of fresh seeds require light and alternating temperatures for maximum germination [29,30], and a diurnal temperature amplitude of $10^{\circ} \mathrm{C}$ is most effective, provided the treatment temperatures are above $10{ }^{\circ} \mathrm{C}$ or below $35^{\circ} \mathrm{C}$ [31] and references therein]. Absence or inhibition of germination of Lolium seeds at temperatures below $5{ }^{\circ} \mathrm{C}$ or above $35{ }^{\circ} \mathrm{C}$ has been observed in many studies, e.g., [32-36]. The optimal temperature for a rapid rate of L. rigidum seed germination is between $20{ }^{\circ} \mathrm{C}$ and $26^{\circ} \mathrm{C}[29]$.

When mature L. rigidum seeds (containing a relatively low amount of water, e.g., 5\%-10\%) are stored under warm, dry conditions, they gradually lose dormancy. The proportion of seeds germinating in a population increases with the time spent dry after-ripening following harvest, and higher temperatures result in a faster rate of dormancy release [34], although extended periods at high temperatures can be associated with seed ageing and loss of viability [29,34]. The progression of dry after-ripening causes the germination requirements of the seed to become more flexible: fully after-ripened L. rigidum seeds can germinate in the dark and/or under constant temperature, as long as it is above the base temperature of $\sim 5^{\circ} \mathrm{C}$ required for germination [34,36]. After-ripened L. rigidum seeds also become less sensitive to inhibition of germination by abscisic acid (Figure 2). 
Figure 2. Differing abscisic acid (ABA) sensitivities of non-dormant L. rigidum seed populations. After-ripened and non-after-ripened seeds (4 replicates of 50 seeds) were incubated on agar containing $0-50 \mu \mathrm{M} A B A$ at $25 / 15^{\circ} \mathrm{C}$ with a $12 \mathrm{~h}$ photoperiod for $42 \mathrm{~d}$, after which final germination percentage (A) and time to $50 \%$ germination (B) were calculated. As the final germination percentage of non-after-ripened seeds exposed to $50 \mu \mathrm{M}$ ABA did not reach $50 \%$, the time to $50 \%$ germination could not be calculated, but was plotted as $42 \mathrm{~d}$. Different letters above columns indicate significant differences $(P<0.05)$ between means.

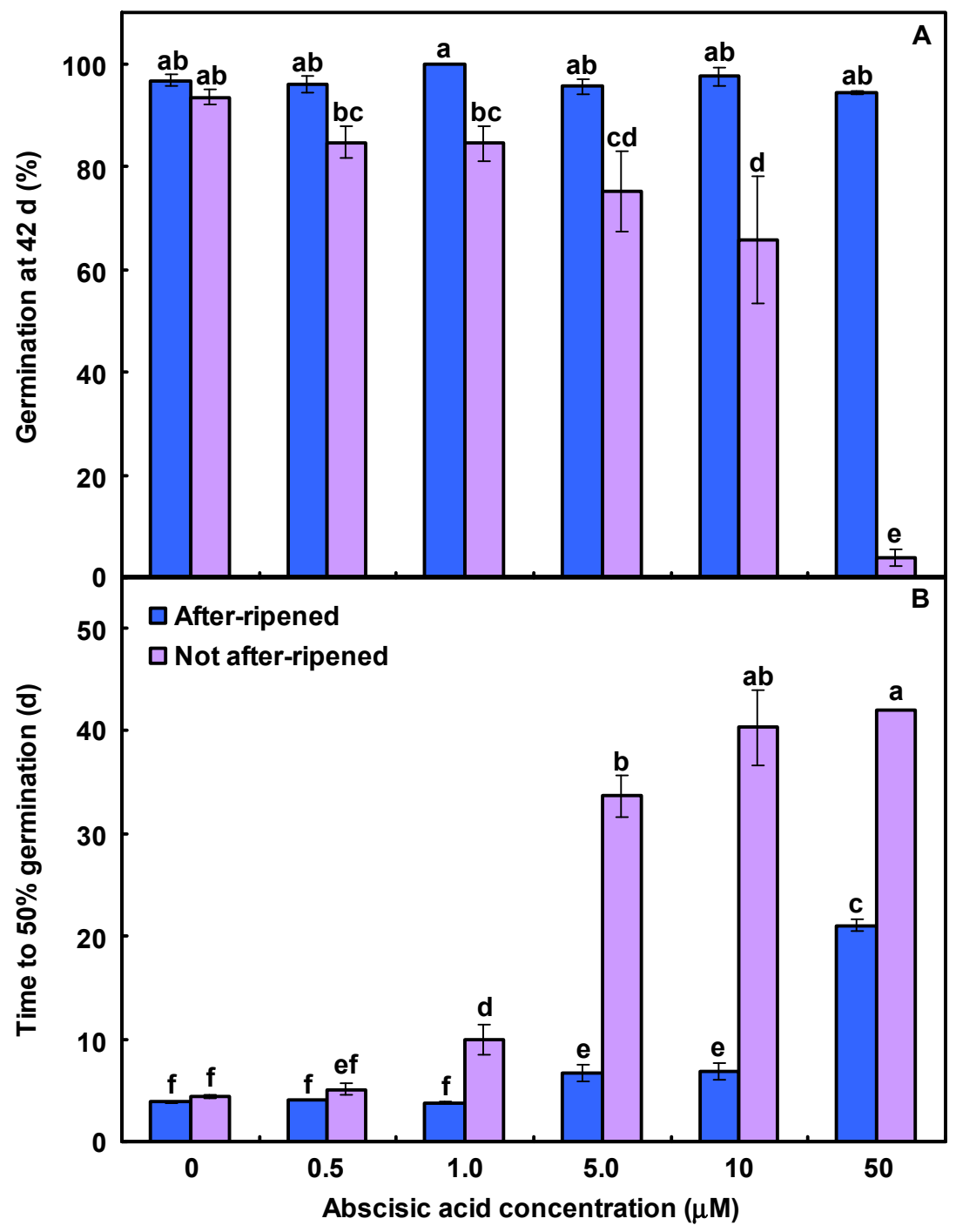

A higher seed moisture content (up to $18 \%$ ) leads to a faster rate of dormancy release via after-ripening, and it has been proposed that promotion of dormancy release at higher temperatures and moisture contents is linked to increases in membrane fluidity and the activity of the enzymes responsible for membrane modifications [34]. Under field conditions, however, the relatively small differences in L. rigidum seed moisture content (ranging between $6 \%$ and $12 \%$ ) caused by fluctuations in air humidity during the summer drought did not affect the rate of dormancy release with respect to accumulation of thermal after-ripening time [37]. Intermittent, full hydration (i.e., wet-dry cycling) of 
seeds does increase rate of dormancy release [38]. Even a single, partial-hydration event (over $10 \mathrm{~d}$ within a 12-week after-ripening period) can increase subsequent seed germinability, particularly if it occurs early during after-ripening [39]. A similar effect of transient hydration has been observed in other studies on L. rigidum [28,40,41], and hydration of already non-dormant seeds can reduce the lag period between imbibition and germination $[38,42]$. The decrease in dormancy in response to wet-dry cycling is likely to be due to alterations in seed abscisic acid and gibberellin concentrations, and/or the sensitivity of the seed to these hormones [43]. From a physiological point of view, germination of L. rigidum seeds after the first substantial rain in a year with a dry summer and autumn (i.e., where no transient seed hydration occurred), would be more staggered and reach lower levels compared to years that have experienced some summer rainfall, thus making weed eradication and subsequent seed bank depletion more difficult. Overall, the loss of dormancy via dry after-ripening over summer contributes to the relatively short persistence of L. rigidum seeds in the seed bank and shortens the period over which a population will germinate, making weed control somewhat easier. However, particularly in populations with a high level of initial dormancy, or in areas where conditions are less conducive to after-ripening, agronomic techniques that stimulate uniform germination (e.g., cultivation or chemical application: see Section 3.4) or prevent seed set are required to help deplete the weed seed bank.

Release of primary dormancy also occurs in hydrated seeds (stratification) in the dark [44], which increases the sensitivity of the seeds to light [45] and gibberellins [46] and decreases sensitivity to abscisic acid [47], permitting a greater proportion of the population to germinate when transferred to conditions of alternating light and temperature. A major difference between seed populations that have lost dormancy via dry after-ripening and those that have experienced dark stratification is that the latter still have a light requirement for germination. Although seeds from some species can be stimulated to germinate by a single, brief flash of light (e.g., [24]), which could occur during soil cultivation, dark-stratified L. rigidum seeds require at least $8 \mathrm{~h}$ of continuous light before germination can commence $[28,44]$. This means that practical application of dark stratification as a means of stimulating germination and depleting the weed seed bank is likely to be challenging, although it is useful for research into mechanisms of dormancy maintenance and release and may be relevant in situations where seeds previously buried in moist soil are brought to the surface by tillage.

\subsection{Interaction of Lolium Seed Germination and Agronomic Practices}

Seed burial depth has a large impact on L. rigidum germination, with shallow-buried seeds showing higher germination than those either on the soil surface or buried deeply; this implies that the methods employed for soil cultivation and crop sowing are highly relevant to manipulation of the weed seed bank. Early laboratory studies on germination of non-dormant L. rigidum seeds demonstrated that whilst seeds buried at $2 \mathrm{~cm}$ or $5 \mathrm{~cm}$ germinated to $70 \%-80 \%$ after up to 8 weeks of burial, $40 \%$ of seeds buried below $8 \mathrm{~cm}$ suffered death and the remainder did not germinate $[28,40]$. In experiments performed in Mediterranean-type climates, L. rigidum seeds buried in soil at shallow depths of $1-5 \mathrm{~cm}$, such as would result from an intermediate level of soil cultivation $(65 \%$ of L. rigidum seeds were moved to this depth by cultivating the soil with $100 \mathrm{~mm}$ tines [48]), showed higher germination than seeds on the soil surface, presumably due to the greater availability of moisture below the surface $[40,41,49,50]$. For example, L. rigidum seed germination in South Australian soils subjected to 
cultivation to depths of $8-10 \mathrm{~cm}$ was more than twice as high as that in soils with no tillage, and reached $50 \%$ of its final value at least a week earlier [48]. Seeds on the soil surface tend to suffer greater decay and predation than those buried through soil cultivation $[14,41,50]$ and the seedlings emerging from surface seeds are less vigorous and thus less likely to set large numbers of viable seeds [50]. Therefore, in the widely practiced no-till farming system in Australia, where up to 85\% of L. rigidum seeds remain in the top $0-1 \mathrm{~cm}$ of the soil [48], significant depletion of the seed bank could potentially be achieved by allowing shed seeds to remain on the soil surface and be removed naturally through decay and predation; this, in contrast to a system of shallow soil cultivation to stimulate uniform germination, also has the advantage of not requiring removal of the germinated weed seedlings before sowing the crop.

Emergence of Lolium spp. seeds buried deeper than $5 \mathrm{~cm}$ below the soil surface is impeded, either through inhibition of germination due to the lack of temperature variation, loss of seed viability through ageing under the moist conditions, or because of an inability of the coleoptile to reach the soil surface before seed reserves are exhausted (e.g., [12,36,51,52]). Mouldboard ploughing, to depths of 15-35 cm, reduced L. rigidum emergence by 50\%-100\% at multiple sites in both Spain [53] and Australia [54]. However, although germination of L. rigidum seeds is inhibited by deep burial, this inhibition is readily reversed by transferring the seeds close to the soil surface, where the diurnal fluctuation in temperature is much greater [28,40], and presumably oxygen is more readily available. Therefore, the potential advantages of soil cultivation to encourage early weed germination have to be weighed against the possibility that deeper-buried seeds may remain to germinate in the next season if cultivation is used again and they are brought to the surface.

Studies on a possible link between Lolium seed traits and herbicide resistance have given varying results. There was a slight tendency for herbicide-susceptible L. rigidum plants to produce more seeds than glyphosate-resistant plants, but the resistant plants performed better under crop competition [55]. No strong correlation between seed dormancy and herbicide resistance was found by Recasens et al. [25] or Gill et al. [56] in L. rigidum, but Vila-Aiub et al. [36] and Ghersa et al. [57] reported that herbicide-resistant populations of L. rigidum and L. multiflorum, respectively, tended to germinate slightly later than their herbicide-susceptible counterparts. In the former case, this was due to a slower rate of dormancy release via dry after-ripening and a stricter requirement for alternating light and temperature in the resistant population [36]. It is likely that agronomic practices are responsible for the later germination of herbicide-resistant populations, rather than a genetic or biochemical link existing directly between dormancy level and herbicide resistance [58,59]. Lolium rigidum seeds that are more dormant do not germinate until after the crop has been sown, and thus avoid the pre-sowing application of non-selective herbicides. As a consequence, a higher level of seed dormancy is gradually selected in the population as the early-germinating cohort is removed. These later-emerging plants are exposed to the selective herbicides applied to the crop, which can result in the evolution of resistance within four generations [60]. The co-occurrence of higher dormancy and higher herbicide resistance is therefore rapidly achieved in a field that is constantly cropped, even in the absence of a direct link between dormancy and herbicide resistance [59]. 


\section{Depletion of the $L$. rigidum Seed Bank}

Although traditional soil cultivation is highly effective in depleting the weed seed bank through bringing seeds into the light and increasing the diurnal temperature fluctuation experienced by the seeds [61] (both of which are stimulants of L. rigidum germination [29]), no-till farming under dry Australian conditions has helped to increase crop establishment and yield by preventing soil moisture loss and preserving soil structure and organic matter [62]. Therefore, this section provides an overview of alternative methods of depleting the weed seed bank, which can be achieved by targeting various stages of the plant life cycle: preventing flowering and/or seed set, removal of flower spikes before seeds are shed, killing mature seeds or preventing them from entering the soil, or manipulating germination so it is either prevented or occurs synchronously at an appropriate time for efficient weed removal. These individual methods may not be as effective as soil cultivation, but could be incorporated into an integrated seed bank management system under no-till farming conditions.

\subsection{Prevention of Seed Set}

Preventing seed-set of L. rigidum can halve the number of plants emerging the following season (reviewed in [11]). Increased competition from the crop or from other weed plants (i.e., a higher plant density) can decrease the reproductive output of Lolium spp. by $50 \%-90 \%$ [63-69], largely due to the light deficiency caused by high plant densities. Application of herbicides can inhibit seed production and reduce, by as much as $80 \%$, the viability and vigour of those seeds that are produced [70-72]. Narwal et al. [12] proposed that in order to completely deplete the L. rigidum seed bank, it is necessary to prevent further seed production for 18 to 24 months, which could involve including a pasture rotation in the affected field. A combination of imposing a legume pasture phase, strategic intensive grazing and application of glyphosate to the L. rigidum seed heads protruding above the legume pasture was also suggested to be effective at minimising replenishment of the weed seed bank [73].

\subsection{Removal of Flower Spikes before Seed Shedding}

Removal of mature seeds by livestock grazing appears to be only partially effective, as not only are some seeds inaccessible to livestock (e.g., are lying on the soil surface), but $4 \%-12 \%$ of ingested L. rigidum seeds can pass unharmed through the digestive tract and germinate, possibly far from where they were originally shed unless the animals are not moved for several days following ingestion of seeds [74]. Sheep consume the seeds still held in the inflorescence spikes, so that grazing during spring, before the seeds have matured and started to shed, can remove up to $80 \%$ of seeds [75].

\subsection{Killing or Removing Mature Seeds}

Practices such as mulching or cover cropping, which retain moisture near the soil surface but are inhibitory to germination due to lack of light, may help to deplete the seed bank more rapidly by encouraging faster rates of moisture-dependent deteriorative processes such as seed ageing and microbial attack. For example, $50 \%-90 \%$ of L. rigidum seeds kept at a moisture content of 33\% lost viability over six weeks at moderate temperatures $\left(15-20^{\circ} \mathrm{C}\right)$, whilst seeds containing $10 \%$ moisture remained completely viable over the same time period [11]. Infection of non-dormant Lolium spp. 
seeds with a range of pathogenic fungi isolated from seeds or soil resulted in germination levels of only $20 \%-50 \%$ [76,77], illustrating the potential effectiveness of higher moisture levels in decreasing seed viability. Similarly, irradiating the soil with microwaves for several minutes can reduce the viability of the L. rigidum and L. perenne seed bank to almost zero, particularly in moist sand, as long as the seeds are near the soil surface [78].

Catching and removing L. rigidum seeds during crop harvest can decrease the number of seeds entering the seed bank by $60 \%$ [66] or $75 \%-85 \%$ [79], provided that the harvest is carried out before the heads have started to shed their seeds. Destruction of the weed seeds by passing them through a mill during the harvesting process [80] eliminates the need for physical collection and removal of the chaff, which can then be left on the soil surface and return nutrients to the system without the seed bank becoming replenished.

Seed predation by ants also has potential to be used as a means of L. rigidum control. Ants were responsible for removal of more weed seeds from a summer fallow field than were rodents, birds and large invertebrates combined, and they have a preference for L. rigidum seeds over those of other, larger-seeded species [81]. By using agronomic practices, such as minimising both insecticide use and soil cultivation, the contribution of ants to decreasing the L. rigidum seed bank could be enhanced [81].

\subsection{Manipulating Seed Germination}

Paraquat, used late season to prevent seed set in post-flowering Lolium spp. plants, can also inhibit germination of the mature seeds by $80 \%-100 \%$ [82-84]. Other, less toxic, allelochemicals that are derived from plants are inhibitory to germination and seedling growth of Lolium spp., and some of these compounds may have potential as alternatives to herbicides in systems where widespread resistance is a problem (e.g., [85-91]). Aqueous extracts from a wide variety of wheat cultivars inhibited germination of $L$. rigidum seeds, and root growth was inhibited to an even greater extent than seed germination [92]. Likely candidates contributing to wheat allelopathy were phenolic compounds and short-chain fatty acids. The fact that these chemicals accumulate in the upper layers of the soil, where the ryegrass seeds are also found, means that highly allelopathic wheat cultivars could offer an alternative means of weed control [92].

Synchronising L. rigidum seed germination for more efficient removal of the seedlings is another control option. Although the smoke-derived karrikinolide molecule [93] can stimulate the uniform germination of a wide range of weed and crop species, it is largely ineffective on L. rigidum germination [94], as is gibberellic acid [47]. However, fluridone, a widely-used bleaching herbicide in aquatic systems in the United States, can release dormancy in L. rigidum more effectively than can dark-stratification [47] and results in bleached seedlings which die before reaching the 3-leaf stage. This would avoid the necessity of spraying the germinated seedlings with another herbicide in order to effect weed removal, and add to the diversity of chemical options available for control of L. rigidum. The potential for fluridone to be used as a combination germination stimulant and herbicide is currently being investigated. 


\section{Modelling L. rigidum Seedling Emergence}

It is well-accepted that accurate prediction of the timing and extent of weed emergence would greatly improve weed management because it would allow informed decisions to be taken by farmers and agronomists $[8,95]$. For example, if it were known in advance that a particular seed bank had low dormancy and would be likely to maximally germinate with the first rains of the season, then a slight delay in crop seeding and a concerted effort to remove the weed seedlings would be worthwhile. Conversely, if it were known that emergence was likely to occur later in the season and have an adverse impact on crop yields, then the decision to move into a fallow or pasture year or to sow a green manure crop would become more attractive.

Development of a prediction tool will require integration of the processes relating to development of dormancy, release of dormancy, and initiation of germination. Prediction of the status of the seed bank for one particular field over time is definitely attainable, but scaling it to the level of a farm or region is complex because of the wide variation in dormancy (e.g., Figure 3). This variation is largely due to the interaction of genetics and environment, but other factors such as management history (e.g., additional Lolium spp. still being sown as a pasture in some fields; selection for dormancy through non-selective or pre-emergent herbicide use) can also influence seed bank dormancy status across a region.

Figure 3. Variations in initial seed dormancy and rate of after-ripening in L. rigidum populations collected from three different sites on the same farm in the Western Australian wheat belt $\left(33^{\circ} 02^{\prime} \mathrm{S}, 116^{\circ} 87^{\prime} \mathrm{E}\right)$. Seeds were after-ripened over summer and early autumn in mesh bags on the soil surface (protected from rainfall and predation) at the farm. Sub-samples of each population were sown under conditions of $25 / 15^{\circ} \mathrm{C}$ with a $12 \mathrm{~h}$ photoperiod at regular intervals over $97 \mathrm{~d}$ (4 replicates of 50 seeds) and germination was counted $21 \mathrm{~d}$ after sowing.

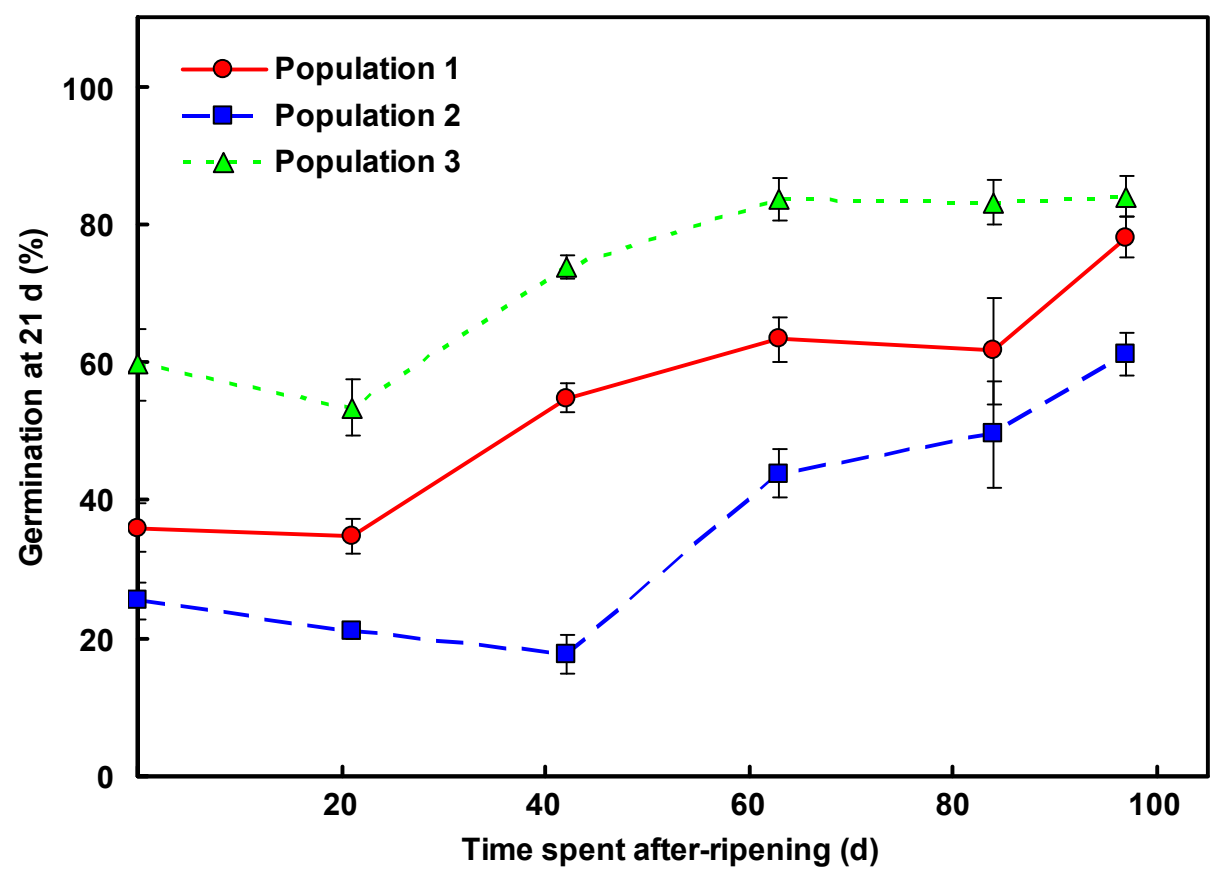


There are two broad approaches for modelling seed emergence, but both are inevitably population-based and are associated with some error. The first approach is to take observed emergence and climate data and use them to create a model (e.g., [96]); the second is to combine a number of models for each separate process that influences changes in dormancy status and germination requirements, such as temperature, moisture and light conditions (e.g., [61]). For optimum performance, the latter approach would then also need additional models to be incorporated: e.g., the number and dormancy status of seeds at the point that they join the seed bank; a longevity parameter to account for seeds that do not germinate within the first year of shedding; and a means of accounting for seed depth in the seed bank and the changes brought about by management practices such as cultivation. The Weed Seed Wizard model [97] was designed along these lines, and the prototype has shown that crop losses due to a theoretical L. rigidum population which is developing resistance to diclofop-methyl (thus making the plants progressively harder to remove) can be greatly reduced by employing management scenarios that prevent $L$. rigidum seed set and deplete the seed bank. Another purpose of the model is to enhance the sustainability of cropping systems by providing users with insights as to how weed seed bank levels are affected by the interaction of a variety of environmental and management factors [97].

\section{Conclusions}

In the battle against the L. rigidum plants infesting cropping systems worldwide, the role of the seed bank, and particularly seed dormancy, is often overlooked. Removal of the current visible weed population does not mean that a field will be weed-free the next year. The fact that germination of L. rigidum seeds is so often staggered due to a continuum of the dormancy levels and specific germination requirements within a population means that some plants will always escape management practices such as cultivation and herbicide application, and survive to replenish the seed bank once more. Although traditional cultivation or ploughing is an effective tool for depleting the weed seed bank, under dry Australian conditions retention of soil moisture and preservation of soil structure and organic matter by minimising cultivation is important. Taking advantage of the relatively short term persistence by using a fallow period for a problem field provides the best opportunity to deplete the seed bank; the growing season following a cool spring, and a cool summer with little or no rainfall, is most likely to be associated with deeper seed dormancy and so greater in-crop weed growth (and consequently greater impact on crop yields) and so would be the best year to go fallow. Otherwise, integrating a number of management tactics directed at various stages of the lifecycle is key to dealing with weeds such as L. rigidum [98], and in a no-till farming system these should include: (1) preventing replenishment of the seed bank each year by preventing seed set and removing/destroying seeds before they are shed; (2) preventing seeds that do shed from entering the soil and encouraging their predation/decay; (3) promoting early, synchronous germination through shallow cultivation and/or chemical stimulants to allow efficient weed removal. 


\section{Acknowledgements}

This work was funded by the Australian Research Council, Linkage Project LP0990923. We are grateful to Natalie Hogg for data in Figure 3, and Rowena Long, Neree Martinez, Mechelle Owen and three anonymous reviewers for helpful comments on the manuscript.

\section{References}

1. Henzell, T. Australian Agriculture: Its History and Challenges; CSIRO Publishing: Collingwood, Australia, 2007.

2. Kloot, P.M. The genus Lolium in Australia. Aust. J. Bot. 1983, 31, 421-435.

3. Appleby, A.P.; Olson, P.D.; Colbert, D.R. Winter wheat yield reduction from interference by Italian ryegrass. Agron. J. 1976, 68, 463-466.

4. Reeves, T.G. Effect of annual ryegrass (Lolium rigidum Gaud.) on yield of wheat. Weed Res. 1976, 16, 57-63.

5. Palta, J.A.; Peltzer, S. Annual ryegrass (Lolium rigidum) reduces the uptake and utilisation of fertiliser-nitrogen by wheat. Aust. J. Agric. Res. 2001, 52, 573-581.

6. Gill, G.S. Why annual ryegrass is a problem in Australian agriculture. Plant Prot. Q. 1996, 11, 193-195.

7. Moore, R.M. Weeds and weed control in Australia. J. Aust. Inst. Agric. Sci. 1971, 37, 181-191.

8. Pannell, D.J.; Stewart, V.; Bennett, A.; Monjardino, M.; Schmidt, C.; Powles, S.B. RIM: A bioeconomic model for integrated weed management of Lolium rigidum in Western Australia. Agric. Syst. 2004, 79, 305-325.

9. Owen, M.J.; Walsh, M.J.; Llewellyn, R.S.; Powles, S.B. Widespread occurrence of multiple herbicide resistance in Western Australian annual ryegrass (Lolium rigidum) populations. Aust. J. Agric. Res. 2007, 58, 711-718.

10. Steadman, K.J.; Ellery, A.J.; Chapman, R.; Moore, A.; Turner, N.C. Maturation temperature and rainfall influence seed dormancy characteristics of annual ryegrass (Lolium rigidum). Aust. J. Agric. Res. 2004, 55, 1047-1057.

11. Ellery, A.J.; Gallagher, R.S.; Dudley, S.V. Dormancy and germination ecology of annual ryegrass (Lolium rigidum Gaud.); In Biology of Seeds: Recent Research Advances; Nicolas, G., Bradford, K.J., Come, D., Pritchard, H.W., Eds.; CABI Publishing: New York, NY, USA, 2003; pp. 389-396.

12. Narwal, S.; Sindel, S.M.; Jessop, R.S. Dormancy and longevity of annual ryegrass (Lolium rigidum) as affected by soil type, depth, rainfall, and duration of burial. Plant Soil 2008, 310, 225-234.

13. Peltzer, S.; Matson, P. Understanding the weed seed bank life of important agricultural weeds. In Proceedings of the Crop Updates, Perth, Australia, 25-26 February 2002; Government of Western Australia: Perth, Australia, 2002.

14. Jensen, P.K. Longevity of seeds of Poa pratensis and Lolium perenne as affected by simulated soil tillage practices and its implications for contamination of herbage seed crops. Grass Forage Sci. 2010, 65, 85-91. 
15. Rampton, H.H.; Ching, T.M. Longevity and dormancy in seeds of several cool-season grasses and legumes buried in soil. Agron. J. 1966, 58, 220-222.

16. Rampton, H.H.; Ching, T.M. Persistence of crop seeds in soil. Agron. J. 1972, 62, 272-277.

17. Tan, M.-K.; Sharp, P.J.; Lu, M.-Q.; Howes, N. Genetics of grain dormancy in a white wheat. Aust. J. Agric. Res. 2006, 57, 1157-1165.

18. Foley, M.E.; Fennimore, S.A. Genetic basis for seed dormancy. Seed Sci. Res. 1998, 8, 173-182.

19. Goggin, D.E.; Emery, R.J.N.; Powles, S.B.; Steadman, K.J. Initial characterisation of low and high seed dormancy populations of Lolium rigidum produced by repeated selection. J. Plant Physiol. 2010, 167, 1282-1288.

20. Wiesner, L.E.; Grabe, D.F. Effect of temperature preconditioning and cultivar on ryegrass (Lolium sp.) seed dormancy. Crop Sci. 1972, 12, 760-764.

21. Owen, M.J.; Michael, P.J.; Renton, M.; Steadman, K.J.; Powles, S.B. Towards large-scale prediction of Lolium rigidum emergence. I. Can climate be used to predict dormancy parameters? Weed Res. 2011, 51, 123-132.

22. Batlla, D.; Kruk, B.C.; Benech-Arnold, R.L. Very early detection of canopy presence by seeds through perception of subtle modifications in red: Far red signals. Funct. Ecol. 2000, 14, 195-202.

23. Mancinelli, A.L. Some thoughts about the use of predicted values of the state of phytochrome in plant photomorphogenesis research. Plant Cell Environ. 1988, 11, 429-439.

24. Casal, J.J.; Sánchez, R.A. Phytochromes and seed germination. Seed Sci. Res. 1998, 8, 317-329.

25. Recasens, J.; Caimons, O.; Torra, J.; Taberner, A. Variation in seed germination and early growth between and within acetolactate synthase herbicide resistant and susceptible Lolium rigidum accessions. Seed Sci. Technol. 2007, 35, 32-47.

26. Baskin, C.C.; Baskin, J.M. Seeds: Ecology, Biogeography, and Evolution of Dormancy and Germination; Academic Press: San Diego, CA, USA, 1998.

27. Schafer, D.E.; Chilcote, D.O. Factors influencing persistence and depletion in buried seed populations. II. The effects of soil temperature and moisture. Crop Sci. 1970, 10, 342-345.

28. Gramshaw, D.; Stern, W.R. Survival of annual ryegrass (Lolium rigidum Gaud.) seed in a Mediterranean type environment. II Effects of short-term burial on persistence of viable seed. Aust. J. Agric. Res. 1977, 28, 93-101.

29. Gramshaw, D. Germination of annual ryegrass seeds (Lolium rigidum Gaud.) as influenced by temperature, light, storage environment, and age. Aust. J. Agric. Res. 1972, 23, 779-787.

30. Gramshaw, D. Temperature/light interactions and the effect of seed source on germination of annual ryegrass (Lolium rigidum Gaud.) seeds. Aust. J. Agric. Res. 1976, 27, 779-786.

31. Shen, J.B.; Xu, L.Y.; Jin, X.Q.; Chen, J.H.; Lu, H.F. Effect of temperature regime on germination of seed of perennial ryegrass (Lolium perenne). Grass Forage Sci. 2008, 63, 249-256.

32. Hill, M.J.; Pearson, C.J.; Kirby, A.C. Germination and seedling growth of prairie grass, tall fescue and Italian ryegrass at different temperatures. Aust. J. Agric. Res. 1985, 36, 13-24.

33. Turner, N.C.; Thomson, C.J.; Rawson, H.M. Effect of temperature on germination and early growth of subterranean clover, capeweed and ryegrass. Grass Forage Sci. 2001, 56, 97-104.

34. Steadman, K.J.; Crawford, A.D.; Gallagher, R.S. Dormancy release in Lolium rigidum seeds is a function of thermal after-ripening time and water content. Funct. Plant Biol. 2003, 30, 345-352. 
35. Larsen, S.U.; Andreasen, C. Light and heavy turfgrass seeds differ in germination percentage and mean germination thermal time. Crop Sci. 2004, 44, 1710-1720.

36. Vila-Aiub, M.M.; Neve, P.; Steadman, K.J.; Powles, S.B. Ecological fitness of a multiple herbicide-resistant Lolium rigidum population: Dynamics of seed germination and seedling emergence of resistant and susceptible phenotypes. J. Appl. Ecol. 2005, 42, 288-298.

37. Steadman, K.J.; Bignell, G.P.; Ellery, A.J. Field assessment of thermal after-ripening time for dormancy release prediction in Lolium rigidum seeds. Weed Res. 2003, 43, 458-465.

38. Lush, W.M.; Groves, R.H.; Kaye, P.E. Presowing hydration-dehydration treatments in relation to seed germination and early seedling growth of wheat and ryegrass. Aust. J. Plant Physiol. 1981, 8, 409-425.

39. Gallagher, R.S.; Steadman, K.J.; Crawford, A.D. Alleviation of dormancy in annual ryegrass (Lolium rigidum) seeds by hydration and after-ripening. Weed Sci. 2004, 52, 968-975.

40. Gill, G.S. Ecology of annual ryegrass. Plant Prot. Q. 1996, 11, 195-198.

41. Chauhan, B.S.; Gill, G.; Preston, C. Influence of environmental factors on seed germination and seedling emergence of rigid ryegrass (Lolium rigidum). Weed Sci. 2006, 54, 1004-1012.

42. Lush, W.M.; Groves, R.H. Germination, emergence and surface establishment of wheat and ryegrass in response to natural and artificial hydration-dehydration cycles. Aust. J. Agric. Res. 1981, 32, 731-739.

43. Long, R.L.; Williams, K.; Griffiths, E.M.; Flematti, G.R.; Merritt, D.J.; Stevens, J.C.; Turner, S.R.; Powles, S.B.; Dixon, K.W. Prior hydration of Brassica tournefortii seeds reduces the stimulatory effect of karrikinolide on germination and increases seed sensitivity to abscisic acid. Ann. Bot. 2010, 105, 1063-1070.

44. Steadman, K.J.; Bignell, G.P.; Michael, P.J. Stimulating dormancy release and emergence of annual ryegrass (Lolium rigidum) seeds using short-term hydrated storage in darkness. Aust. J. Agric. Res. 2004, 55, 787-795.

45. Steadman, K.J. Dormancy release during hydrated storage in Lolium rigidum seeds is dependent on temperature, light quality, and hydration status. J. Exp. Bot. 2004, 55, 929-937.

46. Goggin, D.E.; Powles, S.B.; Toorop, P.E.; Steadman, K.J. Dark-mediated dormancy release in stratified Lolium rigidum seeds is associated with higher activities of cell wall-modifying enzymes and an apparent increase in gibberellin sensitivity. J. Plant Physiol. 2011, 168, 527-533.

47. Goggin, D.E.; Steadman, K.J.; Emery, R.J.N.; Farrow, S.C.; Benech-Arnold, R.L.; Powles, S.B. ABA inhibits germination but not dormancy release in mature imbibed seeds of Lolium rigidum Gaud. J. Exp. Bot. 2009, 60, 3387-3396.

48. Chauhan, B.S.; Gill, G.; Preston, C. Influence of tillage systems on vertical distribution, seedling recruitment and persistence of rigid ryegrass (Lolium rigidum) seed bank. Weed Sci. 2006, 54, 669-676.

49. Cheam, A.; Hashem, A.; Bowran, D.; Lee, A. Autumn tickle can influence dormancy and breakdown of wild radish and annual ryegrass seeds. In Proceedings of the Crop Updates, Perth, Australia, 23-24 February 1998; Government of Western Australia: Perth, Australia, 1998.

50. Chauhan, B.S.; Gill, G.S.; Preston, C. Effect of seeding systems and dinitroaniline herbicides on emergence and control of rigid ryegrass (Lolium rigidum) in wheat. Weed Technol. 2007, 21, 53-58. 
51. Andrews, M.; Douglas, A.; Jones, A.V.; Milburn, C.E.; Porter, D.; McKenzie, B.A. Emergence of temperate pasture grasses from different sowing depths: Importance of seed weight, coleoptile plus mesocotyl length and shoot strength. Ann. Appl. Biol. 1997, 130, 549-560.

52. Sinclair, K.; Beale, P.J. Critical factors influencing no-till establishment of short-term ryegrass (Lolium multiflorum) into a kikuyu (Pennisetum clandestinum) pasture. Crop Pasture Sci. 2010, 61, 192-200.

53. Cirujeda, A.; Taberner, A. Cultural control of herbicide-resistant Lolium rigidum Gaud. populations in winter cereal in northeastern Spain. Span. J. Agric. Res. 2009, 7, 146-154.

54. Newman, P. Mouldboard ploughing of sandplain soils-More grain, fewer weeds. In Proceedings of the Crop Updates, Perth, Australia, 21-22 February 2011; Government of Western Australia: Perth, Australia, 2011.

55. Pedersen, B.P.; Neve, P.; Andreasen, C.; Powles, S.B. Ecological fitness of a glyphosate-resistant Lolium rigidum population: Growth and seed production along a competition gradient. Basic Appl. Ecol. 2007, 8, 258-268.

56. Gill, G.S.; Cousens, R.D.; Allan, M.R. Germination, growth, and development of herbicide resistant and susceptible populations of rigid ryegrass (Lolium rigidum). Weed Sci. 1996, 44, 252-256.

57. Ghersa, C.M.; Martínez-Ghersa, M.A.; Brewer, T.G.; Roush, M.L. Selection pressures for diclofop-methyl resistance and germination time of Italian ryegrass. Agron. J. 1992, 86, 823-828.

58. Gundel, P.E.; Martínez-Ghersa, M.A.; Ghersa, C.M. Dormancy, germination and ageing of Lolium multiflorum seeds following contrasting herbicide selection regimes. Eur. J. Agron. 2008, 28, 606-613.

59. Owen, M.J.; Michael, P.J.; Renton, M.; Steadman, K.J.; Powles, S.B. Towards large-scale prediction of Lolium rigidum (annual ryegrass) emergence. II. Correlation between dormancy and herbicide resistance levels suggests an impact of cropping systems. Weed Res. 2011, 51, 133-141.

60. Neve, P.; Powles, S. Recurrent selection with reduced herbicide rates results in the rapid evolution of herbicide resistance in Lolium rigidum. Theor. Appl. Genet. 2005, 110, 1154-1166.

61. Batlla, D.; Benech-Arnold, R.L. Predicting changes in dormancy level in weed seed soil banks: Implications for weed management. Crop Prot. 2007, 26, 189-197.

62. Ashworth, M.; Desbiolles, J.; Tola, E. Disc Seeding in Zero-Till Farming Systems: A Review of Technology and Paddock Issues; Western Australian No-Tillage Farmer's Association: Northam, Australia, 2010.

63. Mutikainen, P.; Walls, M.; Ojala, A. Effects of simulated herbivory on tillering and reproduction in an annual ryegrass, Lolium remotum. Oecologia 1993, 95, 54-60.

64. Warringa, J.W.; Marinissen, M.J. The effect of light intensity after anthesis on dry matter distribution and seed yield of Lolium perenne L. Grass Forage Sci. 1996, 51, 103-110.

65. Hashem, A.; Radosevich, S.R.; Roush, M.L. Effect of proximity factors on competition between winter wheat (Triticum aestivum) and Italian ryegrass (Lolium multiflorum). Weed Sci. 1998, 46, 181-190.

66. Gonzalez-Andujar, J.L.; Fernandez-Quintanilla, C. Modelling the population dynamics of ryegrass (Lolium rigidum) under various weed management systems. Crop Prot. 2004, 23, $723-729$. 
67. Dear, B.S.; Hodge, A.; Lemerle, D.; Pratley, J.E.; Orchard, B.A.; Kaiser, A.G. Influence of forage legume species, seeding rate and seed size on competitiveness with annual ryegrass (Lolium rigidum) seedlings. Aust. J. Exp. Agric. 2006, 46, 627-636.

68. Holman, J.D.; Bussan, A.J.; Maxwell, B.D.; Miller, P.R.; Mickelson, J.A. Persian darnel (Lolium persicum) fecundity response to spring wheat, canola and sunflower interference. Weed Technol. 2006, 20, 430-437.

69. Sim, L.C.; Froud-Williams, R.J.; Gooding, M.J. The influence of winter oilseed rape (Brassica napus ssp. oleifera var. biennis) canopy size on grass weed growth and grass weed seed return. J. Agric. Sci. 2007, 145, 313-327.

70. Walsh, M.J.; Devlin, R.D.; Powles, S.B. Potential for preseason herbicide application to prevent weed emergence in the subsequent growing season. 1. Identification and evaluation of possible herbicides. Weed Technol. 2004, 18, 228-235.

71. Steadman, K.J.; Eaton, D.M.; Plummer, J.A.; Ferris, D.G.; Powles, S.B. Late-season non-selective herbicide application reduces Lolium rigidum seed numbers, seed viability, and seedling fitness. Aust. J. Agric. Res. 2006, 57, 133-141.

72. Chauhan, B.S.; Gill, G.S.; Preston, C. Timing and dose of metolachlor affect rigid ryegrass (Lolium rigidum) control in wheat. Weed Technol. 2007, 21, 225-229.

73. Cobley, B.; Nutt, B. Controlling annual ryegrass seed-set during a pasture legume phase. In Proceedings of the Crop Updates, Perth, Australia, 22-23 February 1999; Government of Western Australia: Perth, Australia, 1999.

74. Stanton, R.; Piltz, J.; Pratley, J.; Kaiser, A.; Hudson, D.; Dill, G. Annual ryegrass (Lolium rigidum) seed survival and digestibility in cattle and sheep. Aust. J. Exp. Agric. 2002, 42, 111-115.

75. Gramshaw, D.; Stern, W.R. Survival of annual ryegrass (Lolium rigidum Gaud.) seed in a Mediterranean type environment. I. Effect of summer grazing by sheep on seed numbers and seed germination in autumn. Aust. J. Agric. Res. 1977, 28, 81-91.

76. Harris, G.S. The periodicity of germination in some grass species. N. Z. J. Agric. Res. 1961, 4, 253-260.

77. Falloon, R.E. Fungi pathogenic to ryegrass seedlings. Plant Soil 1985, 86, 79-86.

78. Brodie, G.; Harris, G.; Pasma, L.; Travers, A.; Leyson, D.; Lancaster, C.; Woodworth, J. Microwave soil heating for controlling ryegrass seed germination. Trans. ASABE 2009, 52, 295-302.

79. Walsh, M.J.; Powles, S.B. Management strategies for herbicide-resistant weed populations in Australian dryland crop production systems. Weed Technol. 2007, 21, 332-338.

80. Walsh, M.J.; Harrington, R.B.; Powles, S.B. Harrington seed destructor: A new nonchemical weed control tool for global grain crops. Crop Sci. 2012, 52, 1343-1347.

81. Jacob, H.S.; Minkey, D.M.; Gallagher, R.S.; Borger, C.P. Variation in postdispersal weed seed predation in a crop field. Weed Sci. 2006, 54, 148-155.

82. Appleby, A.P.; Brenchley, R.G. Influence of paraquat on seed germination. Weed Sci. 1968, 16, 484-485.

83. Watkin, E.M.; Sagar, G.R. Effect of paraquat on seed germination. Weed Res. 1972, 12, 195-198. 
84. Goggin, D.E.; Powles, S.B.; Steadman, K.J. Selection for low or high primary dormancy in Lolium rigidum Gaud seeds results in constitutive differences in stress protein expression and peroxidase activity. J. Exp. Bot. 2011, 62, 1037-1047.

85. Huang, J.H.; Fu, R.; Liang, C.X.; Dong, D.F.; Luo, X.L. Allelopathic effects of cassava (Manihot esculenta Crantz) on radish (Raphanus sativus L.) and (Lolium perenne L.). Allelopath. J. 2010, 25, 155-162.

86. Ammann, N.; Pieterse, P.J. Effects of Artemisia afra leaf extracts on seed germination of selected crop and weed species. S. Afr. J. Plant Soil 2005, 22, 263-265.

87. Petroski, R.J.; Dornbos, D.L.; Powell, R.G. Germination and growth inhibition of annual ryegrass (Lolium multiflorum L.) and alfalfa (Medicago sativa L.) by loline alkaloids and synthetic $\mathrm{N}$-acylloline derivatives. J. Agric. Food Chem. 1990, 38, 1716-1718.

88. Lill, R.E.; McWha, J.A.; Cole, A.L.J. The influence of volatile substances from incubated litter of Pinus radiata on seed germination. Ann. Bot. 1979, 43, 81-85.

89. Pepperman, A.B.; Bradow, J.M. Strigol analogs as germination regulators in weed and crop seeds. Weed Sci. 1988, 36, 719-725.

90. Kato-Noguchi, H.; Macías, F.A. Inhibition of germination and $\alpha$-amylase induction by 6-methoxy-2-benzoxazolinone in twelve plant species. Biol. Plant. 2008, 52, 351-354.

91. Cavalieri, A.; Caporali, F. Effects of essential oils of cinnamon, lavender and peppermint on germination of Mediterranean weeds. Allelopath. J. 2010, 25, 441-451.

92. Wu, H.; Pratley, J.; Haig, T. Phytotoxic effects of wheat extracts on a herbicide-resistant biotype of annual ryegrass (Lolium rigidum). J. Agric. Food Chem. 2003, 51, 4610-4616.

93. Flematti, G.R.; Ghisalberti, E.L.; Dixon, K.W.; Trengove, R.D. A compound from smoke that promotes seed germination. Science 2004, 305, 977.

94. Stevens, J.C.; Merritt, D.J.; Flematti, G.R.; Ghisalberti, E.L.; Dixon, K.W. Seed germination of agricultural weeds is promoted by the butenolide 3-methyl- $2 H$-furo[2,3-c]pyran-2-one under laboratory and field conditions. Plant Soil 2007, 298, 113-124.

95. Forcella, F. Real-time assessment of seed dormancy and seedling growth for weed management. Seed Sci. Res. 1998, 8, 201-209.

96. Schutte, B.J.; Regnier, E.E.; Harrison, S.K.; Schmoll, J.T.; Spokas, K.; Forcella, F. A hydrothermal seedling emergence model for giant ragweed (Ambrosia trifida). Weed Sci. 2008, 56, 555-560.

97. Renton, M.; Peltzer, S.; Diggle, A. Winning the weed war with the Weed Seed Wizard! In Proceedings of the Crop Updates, Perth, Australia, 25-26 February 2007; Government of Western Australia: Perth, Australia, 2007.

98. Anderson, R.L. Managing weeds with a dualistic approach of prevention and control: A review. Agron. Sustain. Dev. 2007, 27, 13-18.

(C) 2012 by the authors; licensee MDPI, Basel, Switzerland. This article is an open access article distributed under the terms and conditions of the Creative Commons Attribution license (http://creativecommons.org/licenses/by/3.0/). 